\title{
OPENNESS, CENTRALIZED WAGE BARGAINING, AND INFLATION
}

\author{
Joseph P. Daniels \\ Associate Professor of Economics \\ Department of Economics \\ Marquette University, Straz Hall, P.O. Box 1881 \\ Milwaukee, WI 53201 \\ Phone: 414-288-3368; Fax: 414-288-5757 \\ E-mail: Joseph.Daniels@marquette.edu \\ Farrokh Nourzad \\ Professor of Economics \\ Department of Economics \\ Marquette University, Straz Hall, P.O. Box 1881 \\ Milwaukee, WI 53201 \\ Phone: 414-288-3570; Fax: 414-288-5757 \\ E-mail: Farrokh.Nourzad@marquette.edu \\ David D. VanHoose \\ Professor of Economics and Herman Lay Professor of Private Enterprise \\ Hankamer School of Business \\ Baylor University, P.O. Box 8003 \\ Waco, TX 76798-8003 \\ Phone/Fax: 254-710-6206 \\ E-mail: David_VanHoose@baylor.edu
}

October 21, 2004

Draft Revision, April 20, 2005

\begin{abstract}
This paper develops a model of an open economy containing both sectors in which wages are market-determined and sectors with wage-setting arrangements. A portion of the latter group of sectors coordinate their wages, taking into account that their collective actions influence the equilibrium inflation outcome in an environment in which the central bank engages in discretionary monetary policymaking. Key predictions forthcoming from this model are (1) increased centralization of wage setting initially causes inflation to increase at low degrees of wage centralization but then, as wage centralization increases, results in an inflation dropoff; (2) a greater degree of centralized wage setting reduces the inflation-restraining effect of greater central bank independence; and (3) increased openness is more likely to reduce inflation in nations with less centralized wage bargaining. Analysis of data for seventeen nations for the period 1970-1999 provides generally strong and robust empirical support for all three of these predictions.
\end{abstract}




\section{OPENNESS, CENTRALIZED WAGE BARGAINING, AND INFLATION}

\section{Introduction}

Early work by Calmfors and Driffill (1988) sought to understand the role of structural heterogeneities as key factors explaining cross-country variations in macroeconomic performance and in the effects of macroeconomic policies. Recently there has been a reemerging interest in this topic. Much of this interest has arisen in the political economy literature [see, for instance, Iversen, Pontusson, and Soskice (2000), and Franzese (2001, 2002, 2004), where considerable attention has been focused on the interaction among wage-bargaining centralization, central bank independence, and inflation performance [specific examples are Iverson (1998, 1999a), Franzese (2001), and Franzese and Hall (1998)].

There is, of course, a burgeoning literature in economics concerning the macroeconomic implications of central bank independence. Only a segment of this body of work, however, has examined the interplay between centralized wagebargaining structures and the equilibrium inflation rate under monetary policy discretion. Nevertheless, important contributions by Cubitt $(1992,1995)$ and Skott (1997) have showed that centralization of wage bargaining can significantly influence the optimal policy choices of a central bank. Following up on this work, Soskice and Iversen (2000), Iversen (1999b), McHugh (2002), Guzzo and Velasco (1999), and Cukierman and Lippi (1999) have developed alternative frameworks for exploring the implications of increased wage-setting centralization for various macroeconomic variables, including inflation. Soskice and Iversen emphasize how real wage adjustments can induce wage setters to accept lower nominal wages in exchange for increased employment, thereby providing a channel by which centralized wage bargaining can influence monetary policymaking and through which policymaking can, in turn, affect negotiated wages, employment, and output. Iversen (1999b) develops a simple extension of the Barro- 
Gordon framework that predicts a nonmonotic, hump-shaped relationship between inflation and the degree of centralized wage bargaining and provides empirical support for this hypothesis. McHugh, who uses a model of imperfect competition in product markets as a means of analysis and examines only extreme labor-market structures (completely decentralized wage bargaining or fully centralized wage setting), reaches the conclusion that greater wage-bargaining centralization unambiguously raises inflation.

The effects of increased central bank conservatism are the main focus of Guzzo and Velasco. In contrast to McHugh, Guzzo and Velasco follow Skott by employing a multi-union model. They find that increased central bank conservatism initially tends to reduce inflation but ultimately may lead to higher inflation if the wage-bargaining process is sufficiently centralized. This implies that in a highly centralized wage-setting environment, society might be better off with a less conservative central bank. Like Guzzo and Velasco and Iversen (1999b), Cukierman and Lippi develop a theory of competing unions in which the degree of centralization can vary with the number of unions involved in wage coordination. Their model implies that there are two ways in which increased centralization of wage bargaining can have macroeconomic effects. One is a strategic effect of greater centralization, in which coordinating unions recognize the inflation-moderating effects of lower wages. Another is a competition effect, in which greater centralization of wage bargaining causes each union in the coordinating group to internalize the tendency of the central bank to respond to wage-bargaining centralization by reducing money growth, thereby reducing the incentive of unions to restrain their coordinated wage demands. The interaction between these effects leads to a hump-shaped relationship between the centralization of wage bargaining and inflation, with inflation initially rising with greater centralization and then declining. In addition, greater central bank independence typically reduces inflation, but at higher degrees of centralized wage setting this effect is reduced (and possibly reversed), 
because in the face inflation-reducing effect of increased central bank conservatism unions have less incentive to restrain wage growth.

A common feature of all these analyses is that they examine closed economies with firms operating in labor markets populated only by wage-setting unions. In reality, of course, many nations have a mix of wage-setting arrangements, including the setting of nominal wages by some agents without regard to the macroeconomic effects of their decisions and by others who recognize that their collective wage decision can have macroeconomic consequences. This paper departs from earlier work by including all three labor-market structures within a single framework: an open economy containing firms without wage contracts, workers that do not coordinate wage-setting activities, and firms employing workers that collectively establish a common nominal wage. The paper uses this framework to evaluate the implications of openness for the relationship between the extent of centralization of wage bargaining and inflation.

Three key predictions emerge from our analysis. First, as in Guzzo and Velasco, Iversen (1999b), and Cukierman and Lippi, inflation initially rises with increased centralization of wage bargaining but then declines. Second, and also in accord with these authors' conclusions, the inflation-restraining effect of increased central bank conservatism is reduced by a greater extent of centralized wage setting. Although these two conclusions echo the implications of these authors' analyses, they emerge from a very different approach in which firms employing workers without nominal wage contracts and firms bargaining with workers with and without centralized wagebargaining arrangements all inhabit the economic environment. Third, our model implies that a greater degree of openness is more likely to reduce inflation in nations with less centralized wage bargaining. When the wage-setting process is more centralized, increased openness can be associated with higher inflation, ceteris paribus. Hence, our model provides a broader indication of the range of interactions among fundamental institutional characteristics—centralization of wage setting, central bank 
independence, and openness - in the determination of national inflation performances, which contrast to some extent with some of the previous literature examining the nature of these interactions (see, for instance, Franzese, 2002).

The next section presents our model. Section 3 uses a closed-economy version of this framework to illustrate how equilibrium inflation varies with the economy's overall degree of wage centralization, as measured by the portion of firms with workers with wage contracts that participate in the joint coordination of wage setting. In section 4 , we show that there are contrasting channels by which increased openness influences the relationship between inflation and the centralization of wage bargaining. Section 5 assesses the empirical implications of our analysis and evaluates the evidence. Section 6 summarizes our conclusions.

\section{An Open Economy with and without Coordinated Wage Setting}

The theoretical framework is based in part on a limiting case of perfectly competitive product markets in the model developed in Daniels and VanHoose (Forthcoming). ${ }^{1}$ There are many atomistic firms in the economy, indexed $i$, which are distributed uniformly along a unit interval. A fraction, $\Omega$, of firms have workforces that contractually set nominal wages in advance of labor-market clearing. Spot labor markets determine nominal wages in the portion of firms, $1-\Omega$, that do not have such contracts. In a closed-economy version of this basic framework, Duca and VanHoose (2001) show that if risk-neutral firms and risk-averse workers face common aggregate shocks and heterogeneously distributed firm-specific disturbances, the contract share of firms $\Omega$ typically lies between zero and unity but declines as the variability of firmspecific disturbances increases relative to the volatility of aggregate shocks. To maintain tractability, we abstract from considerations of disturbances that influence the endogenous determination of the share of firms with nominal wage contract. We also

abstract from a number of microeconomic factors—both institutional and structural-that 
undoubtedly also influence the magnitude of $\Omega$. Consequently, we treat this proportion as an exogenous parameter. This has the potential to limit the applicability of our analysis over a horizon sufficiently long that $\Omega$ might vary endogenously.

The output produced by a given firm $i$ is given by

$$
y_{i}=\alpha l_{i}
$$

where $y_{i}$ is the $\log$ of output and $l_{i}$ is the log of employment at firm $i$. In principle, we could also include a productivity shock, but in the present context we simplify by excluding explicit consideration of such shocks from the analysis.

The domestic nation's income-expenditure equilibrium condition (for a derivation of this Cobb-Douglas approximation, see, for instance, Canzoneri and Henderson, 1991, or Bryson, et. al., 1993) is given by

$$
y=\eta\left(p^{*}+s-p\right)+(1-\beta) y+\beta y^{*}
$$

where $y \equiv \int_{0}^{1} y_{i} \mathrm{~d} i$ is the log of aggregate domestic output; $p \equiv \int_{0}^{1} p_{i} \mathrm{~d} i$ is the log of the aggregate domestic price level; the average propensity to import, $\beta$, is a fraction; $\eta$ is the elasticity of desired spending with respect to the real exchange rate; $p^{*}$ is the log of the aggregate foreign price level; $s$ is the log of the domestic currency price of foreign currency; and $y^{*}$ is the log of aggregate foreign output. Purchasing power parity does not necessarily hold at any point in time, but we assume agents anticipate that purchasing power parity does hold on average, so that $p^{*}+s^{e}-p^{e}=0$, where the superscript $e$ denotes the conditional expectation of a variable given information available in the previous period. Specifying analogous structural relationships for a foreign nation would yield a two-country framework in which $y^{*}$ and $p^{*}$ would be endogenous variables. In this paper, however, we assume the output and prices abroad are exogenously determined. Henceforth we simplify the exposition by 
assuming that the foreign money stock, foreign price level, and foreign output equal unity, so that $p^{*}$ and $y^{*}$ equal zero.

Domestic income is determined by the quantity equation,

$$
y=m-p,
$$

where $m$ is the log of the money stock. We simplify by normalizing velocity at unity, so that the log of velocity equals zero. Consequently, the monetary authority ultimately determines the price level, and hence inflation, through its choice of $m$.

Using (1) in the profit function, $P_{i} Y_{i}-W_{i} L_{i}$, yields the labor demand function for a firm $i$ (with the intercept suppressed because it plays no role in our subsequent analysis):

$$
\text { (4) } \quad l_{i}^{d}=\frac{-\left(w_{i}-p\right)}{1-\alpha}
$$

where $w_{i}$ is the log of the nominal wage for the firm.

Workers can consume both domestically produced output and foreign-produced goods. Consequently, labor supply to firms depends on the real wage computed in terms of the overall price workers pay for a basket of both domestic and foreign goods:

$$
l_{i}^{s}=\lambda\left[w_{i}-(1-\beta) p-\beta s\right],
$$

where $\lambda>0$. For firms with or without nominal wage contracts, the full-information, market-clearing wage satisfies (4) and (5) simultaneously and equals

(6) $\quad \hat{w}_{i}=\frac{[\lambda(1-\alpha)+1] p+\lambda(1-\alpha) \beta(s-p)}{[\lambda(1-\alpha)+1]}$.

This is the wage actually paid by firm $i$ if it is among the share, $1-\Omega$, of firms without nominal wage contracts. Substitution of (6) into either (4) or (5) and the result into (1) yields output of a noncontract firm with market-clearing $(m c)$ wages: 
(7) $\quad y_{i}^{m c}=-\frac{\alpha \lambda \beta(s-p)}{[\lambda(1-\alpha)+1]}$.

Thus, output of a firm without wage contracts responds negatively to a real depreciation of the home currency, because this reduces the purchasing power of workers' wages and thereby generates a ceteris paribus decline in labor supply and hence a decline in spot-market employment at noncontract firms. ${ }^{2}$

Wage setters at the fraction of firms with nominal wage contracts, $\Omega$, set nominal wages to minimize the expected value of the loss function,

$$
L_{i}^{w}=\left[\frac{1}{2}\left(l_{i}-\hat{l}_{i}\right)^{2}+\frac{b_{w}}{2} \pi^{2}\right],
$$

where $\hat{l}_{i}$ is the market-clearing, full-information employment level, which is equal to zero in this simplified model, $\pi$ is inflation, and $b_{w}$ is the relative weight that workers using nominal wage contracts place on the inflation objective relative to the employment objective. As an analytical simplification, we define $\pi \equiv p-p_{-1}$ and normalize last period's price level at zero, so that $\pi=p .^{3}$

As in Cubitt (1992, 1995), Skott (1997), Cukierman and Lippi (1999), we consider a setting in which firms and members of society who supply labor seek to minimize perceived employment and inflation losses Consequently, we assume that wage setters care about inflation losses separately because of associated menu and various other costs (see Modigliani and Fischer, 1986; and Fischer, 1986). In addition, it is commonplace in this literature-and we follow the literature in this regard below-to consider policymaking, and presumably societal, loss functions that incorporate differential concerns about employment and output versus inflation. In our model, wage setters are the main agents of society, hence we assume that concerns about inflation losses separate from inflation losses matter to them as well as to policymakers.

The loss-minimizing condition is 


$$
\mathrm{E}\left(\frac{\partial l_{i}}{\partial w_{i}} I_{i}+b_{w} \frac{\partial p}{\partial w_{i}} p\right)=0
$$

A fraction $\phi$ of contract firms (which are a fraction $\phi \Omega$ of all firms in the economy) coordinate their wage-setting activities. Workers at a firm among the fraction $1-\phi$ that do not coordinate [which are a fraction (1- $\phi) \Omega$ of all firms] recognize that firm-level wage decisions cannot influence the price level, so that $\frac{\partial p}{\partial w_{i}}=0$. Solving (9) thereby yields the contracted nominal wage at a noncoordinating $(n c)$ firm equal to $w_{i}^{n c}=\hat{w}_{i}^{*}=p^{e}$. Substituting the expectation of (6) into (4) and the result into (1) yields output of a firm with a noncoordinated wage contract,

(10) $y_{i}^{n c}=\frac{\alpha\left(p-p^{e}\right)}{(1-\alpha)}$

which responds positively to unanticipated changes in the price level.

At firms with wage setters that cooperatively determine nominal wages, the contract wage at every firm is set at a common level $w^{c}$. Output of a firm among this set with coordinating wage setters is thereby equal to

$$
\text { (11) } y_{i}^{c}=\frac{\alpha\left(p-w^{c}\right)}{(1-\alpha)}
$$

so that output of the firm naturally increases if the price level grows at a faster pace than the coordinated wage rate. From (9) and the fact that for a firm with coordinating wage setters employment is $I_{i}^{c}=\frac{\left(p-w^{c}\right)}{(1-\alpha)}$, this wage rate satisfies

$$
w^{c}=p^{e}-\frac{(1-\alpha)^{2} b_{u} \frac{\partial p^{e}}{\partial w^{c}} p^{e}}{1-\frac{\partial p^{e}}{\partial w^{c}}} .
$$


The wage choice of a group of coordinating wage setters can influence the aggregate price level, so this group sets its wage under the recognition that $\frac{\partial p}{\partial w_{i}^{\text {nc }}}$ is generally nonzero. Thus, as is standard in the literature noted in the Introduction, coordinating wage setters take into account the anticipated price-level effects of their collective wage choice, given by $\frac{\partial p^{e}}{\partial w_{i}^{c}}$, when determining their common contract wage. To proceed in solving the model, therefore, we must determine the relationship between the aggregate price level and the collective wage decision of coordinating wage setters.

\section{Wage-Setting Coordination and Inflation in a Closed Economy}

To understand the basic workings and implications of the model, it is useful, in light of the additional complexities that openness creates, to begin with a closedeconomy version of the framework. This is the case in which $\beta=0$. Firms behave identically, so that $y_{i}^{c}=y^{c}$ for all $i \in[0, \phi \Omega], y_{i}^{n c}=y^{n c}$ for all $i \in[\phi \Omega, \Omega]$, and $y_{i}^{m c}=y^{m c}$ for all $i \in(\Omega, 1]$. It follows that $y=\phi \Omega y^{c}+(1-\phi) \Omega y^{n c}+(1-\Omega) y^{m c}$, where (7) implies that when $\beta=0$, there is no real-exchange-rate effect on output at noncontract firms, so that $y^{m c}=0$. Equations (10), and (11) then imply that the aggregate supply relationship in the closed-economy version of the model is given by

$$
y=\frac{\phi \Omega \alpha\left(p-w^{c}\right)+(1-\phi) \Omega \alpha\left(p-p^{e}\right)}{(1-\alpha)}
$$

Equalizing (13) and the aggregate demand expression in (3) thereby yields the aggregate price level in terms of the common wage set via coordinating bargaining:

$$
p\left(w^{c}\right)=\frac{\alpha \phi \Omega w^{c}+\alpha(1-\phi) \Omega p^{e}+(1-\alpha) m}{[1-\alpha(1-\Omega)]}
$$


This implies that $\frac{\partial p}{\partial w_{i}^{c}}=\frac{\alpha \phi \Omega}{\{1-\alpha[1-(1-\phi) \Omega]\}}$. The effect of establishment of a higher wage by coordinating wage setters on the aggregate price level is positive, because such a wage boost places upward pressure on the equilibrium price level. Coordinating wage setters will anticipate this effect when establishing their collective nominal wage, and equation (12) thereby indicates that the contract wage they establish is given by

$$
w^{c}=\left(1-\frac{\alpha \phi \Omega(1-\alpha)^{2} b_{w}}{\{1-\alpha[1-(1-\phi) \Omega]\}}\right) p^{e}
$$

Hence, if $\phi \Omega$ is nonzero, so that workers at a portion of firms coordinate setting their nominal wages, and $b_{w}>0$, so that wage setters place a positive loss weight on inflation, the contracted nominal wage established at the share of firms with coordinated bargaining will be a markdown from the anticipated price level. This is so because the coordinating wage setters will recognize that a higher collective wage will have inflationary consequences, which they reduce by holding down their common contracted wage. In addition to restraining the price level, this has the effect of boosting employment above the full-information, market-clearing level.

Substituting (15) into (14) yields the equilibrium price level in terms of the money stock and the expected price level:

$$
p=\frac{(1-\alpha)\{1-\alpha[1-(1-\phi) \Omega]\} m+\left\{\alpha \Omega\{1-\alpha[1-(1-\phi) \Omega]\}-(1-\alpha)^{2} \alpha^{2} \phi^{2} \Omega^{2} b_{w}\right\} p^{e}}{[1-\alpha(1-\Omega)]\{1-\alpha[1-(1-\phi) \Omega]\}}
$$

Substitution of (15) and (16) into (13) then produces an expression for aggregate output in terms of the money stock and the expected price level, given by

$$
y=\frac{\alpha \Omega\{1-\alpha[1-(1-\phi) \Omega]\} m-\left\{\alpha \Omega\{1-\alpha[1-(1-\phi) \Omega]\}-(1-\alpha)^{2} \alpha^{2} \phi^{2} \Omega^{2} b_{w}\right\} p^{e}}{[1-\alpha(1-\Omega)]\{1-\alpha[1-(1-\phi) \Omega]\}}
$$


Naturally, (17) implies that the model also has implications for real output, as in Soskice and Iversen (2000), but in this paper we focus solely on examining its inflation predictions.

Following Barro and Gordon, we consider a Nash game among the central bank and wage setters in which the central bank seeks to minimize the policy loss function,

$$
L=E\left[(y-\hat{y}-K)^{2}+b_{c b} \pi^{2}\right]
$$

where $y$ is full-information economy-wide output under market clearing, which equals zero, $K$ is an output distortion, and $b_{c b}$ is the relative weight that the central bank places on the inflation component of its loss function. As in the basic analysis of Barro and Gordon (1983), for $K=0$, a zero-inflation policy minimizes the central bank's loss. In general, however, $K>0$, and because agents make ex ante choices without complete information, a zero-inflation monetary policy is time-inconsistent. In many versions of this Barro-Gordon-style framework, a common assumption is that the inflation rate is a choice variable for the central bank. In this model, however, the central bank determines the money stock. Once the money stock is determined, the equilibrium inflation rate, which with $p_{-1}=0$ is equivalent to the price level, adjusts endogenously to the money stock and agents' expectation of the price level. Hence, the central bank alters the conditions under which wage setters bargain, thereby influencing their wage choices and, ultimately, the price level and real output.

Using (16) and (17) in (18) and minimizing with respect to $m$, with the expected price level taken as given, yields a lengthy expression for the money stock in terms of the expected price level. Equation (16), however, implies that ex post the expected price level is equal to

$$
p^{e}=\frac{\{1-\alpha[1-(1-\phi) \Omega]\} m^{e}}{\{1-\alpha[1-(1-\phi) \Omega]\}-(1-\alpha) \alpha^{2} \phi^{2} \Omega^{2} b_{w}}
$$


Note that as long as $\phi>0$ and $b_{w}>0$, the expected price level does not rise equiproportionately with agents' anticipation of expected money growth, because agents recognize the inflation-restraining effect of coordinating wage setters' incentives to hold back on nominal wage boosts. Finally, substituting (19) into the decision rule for the central bank's optimal money stock choice yields the average price level, which since $p_{-1}$ equals zero is the average inflation rate for the closed-economy version of the model:

(20) $\pi=\frac{\alpha \Omega\{1-\alpha[1-(1-\phi) \Omega]\} K}{(1-\alpha)\left(\{1-\alpha[1-(1-\phi) \Omega]\} b_{c b}+\alpha^{3} \Omega^{3} \phi^{2} b_{w}\right)}$.

Note that this solution indicates that if $\phi=0$, so that no wage setters coordinate their bargaining, or if $b_{w}=0$, so that wage setters place no loss weight on inflation, the equilibrium average inflation rate is $\pi=\frac{\alpha \Omega K}{(1-\alpha) b_{c b}}$. This is the standard Barro-Gordon inflation solution indicating that the magnitude of the inflation bias depends positively on the output distortion $K$ and the terms of the output-inflation trade-off governed by the magnitude of the output elasticity parameter $\alpha$, and negatively on the inflation weight of the central bank, all provided that $\Omega>0$, so that at least a portion of firms in the economy have nominal wage contracts creating nominal wage stickiness and, thus, a time inconsistency problem.

For $\phi>0$ and $b_{w}>0$, a portion of the economy is populated with inflation-averse wage setters that coordinate a common wage choice while recognizing the inflationary consequences of their collective decision. This has a moderating effect on inflation that is increasing in the sizes of both $\phi$ and $b_{w}$. Thus, even though an increase in the overall share of the economy with contracted wages, $\Omega$, tends to increase the scope of the economy's time-inconsistency problem, this effect tends to be mitigated if a larger 
portion of wage setters coordinate their bargaining by holding back on wage boosts to restrain their inflationary consequences.

The magnitude of the share $\phi \Omega$ essentially measures the overall degree of centralization of the economy's wage-bargaining process. Figure 1 displays simulations of (20) under the simplifying assumption that $b_{c b}=b_{w}=b$. In all three simulations shown in the figure, the average inflation rate initially increases as both $\phi$ and $\Omega$ rise but ultimately declines. This implies a hump-shaped relationship between average inflation and the overall share of firms with coordinating wage setters. Although we have, as in Cukierman and Lippi (1999), derived this relationship using a model of discretionary monetary policy, this conclusion accords with the Calmfors-Driffill argument that macroeconomic performance-here captured by effects on average inflation—worsens at intermediate degrees of centralization of wage bargaining but ultimately improves as the centralization of wage bargaining becomes more fully centralized.

\section{[Figure 1 Goes Here]}

As in Barro and Gordon, a larger value of $\alpha$ raises the extent to which unexpected increases in inflation can boost output, which adds to the central bank's incentive to boost the money stock and thereby increases average inflation for all values of $\phi$ and $\Omega$. Decreases in either $b_{c b}$ or, as long as $\phi>0, b_{w}$ act to increase the equilibrium inflation rate. In this sense, the model supports Franzese's (2002) conclusion that central bank independence and increased centralization of wage bargaining both have reinforcing inflation-restraining effects. Equation (20) implies, however, if there is an increased aversion to inflation on the part of coordinating wage setters, so that $b_{w}$ increases in magnitude, a rise in the degree of central bank conservatism reflected by a larger value of $b_{c b}$ has a smaller effect on inflation. 
Ceteris paribus, therefore, greater central bank conservatism in a nation with a larger extent of centralized wage bargaining will tend to reduce inflation less than in a country with a relatively larger share of firms that experience decentralized wage setting. This conclusion is similar to the result in the analysis of Cukierman and Lippi but does not rely on a framework in which the entire labor force is unionized. In addition, because our model includes firms that pay market-clearing wages and considers a loss function with an output objective, greater central bank independence unambiguously tends to reduce inflation. Consequently, in contrast to Cukierman and Lippi, there is no reversal of the effect of central bank independence on inflation, in which an "ultra liberal" central bank that places no weight on inflation can emerge as a loss-minimizing outcome. Even in the case in which $\phi=\Omega=1$, so that workers at all firms contract and engage in coordinated wage setting, an "ultra liberal" central bank is consistent with a loss-minimizing outcome only in the special case in which $\alpha=1$. In this special case, of course, output and employment are identical, and ex ante policy actions involving output loss minimization correspond to the employment-focused policymaking contemplated by Cukierman and Lippi.

\section{Openness, Coordinated Wage Setting, and Inflation}

Our approach also allows for a consideration of the implications of openness for the relationship among centralization of wage bargaining, central bank independence, and inflation. In an open economy, $\beta>0$, and two channels are introduced into the analysis of the determination of equilibrium inflation in the presence of wage-setting coordination among a portion of firms in the economy. First, the aggregate supply relationship that holds for an open economy becomes

$$
\text { (13') } y=\frac{\phi \Omega \alpha\{1-\alpha[1-(1-\phi) \Omega]\}\left(p-w^{c}\right)+(1-\phi) \Omega \alpha\{1-\alpha[1-(1-\phi) \Omega]\}\left(p-p^{e}\right)+(1-\Omega) \lambda \beta(p-s)}{(1-\alpha)\{1-\alpha[1-(1-\phi) \Omega]\}} \text {. }
$$


This solution implies that the sensitivity of output with respect to the price level along the aggregate supply relationship is increasing in the degree of openness, measured by the import propensity, $\beta$. This is so because an increase in openness makes labor supply at noncontract firms relatively less sensitive to variations in the home price level, given the nominal exchange rate. Consider the effect of a rise in the home price level: Labor supply declines in response to the resulting fall in the real wage, and so employment and output decline. This effect is diminished as the degree of openness rises, because greater openness reduces the sensitivity of labor supply with respect to the home price level. Thus, equilibrium output is less sensitive to a change in the price level in a more opening economy, implying that the terms of the overall output-inflation relationship improve as the magnitude of $\beta$ increases.

At the same time, however, combining (2) and (3) indicates that in an incomeexpenditure equilibrium for the home economy, $\frac{\partial p}{\partial m}=\frac{\beta}{\beta-\eta}$, so that $\frac{\partial\left(\frac{\partial p}{\partial m}\right)}{\partial \beta}=\frac{-\eta}{(\beta-\eta)^{2}}<0$. This implies that the responsiveness of aggregate expenditures to a change in the money stock declines with increased openness, which reduces the extent which discretionary monetary policy can influence the price level in an effort to induce output expansions. Together these two effects of increased openness tend to work against each other. Daniels and VanHoose (Forthcoming) show that in an imperfect-competition generalization of this framework the reduced ability of the central bank to induce firms to raise prices, owing to the reduced pricing power available to firms as the degree of openness increases, can tend to dominate and produce lower average inflation, which for most nations is consistent with actual experience. Thus, greater openness is most likely to cause a downward shift in the open-economy analogue to the relationship between openness and the degree of wage centralization depicted in Figure 1. 
The second channel arises from the fact that increased openness affects the incentives of coordinating wage setters. Because the aggregate supply relationship is shallower in a more open economy, an increase in wages set via centralized wage bargaining has a smaller effect on the aggregate price level. This, in turn, reduces the incentive for wage setters that coordinate their bargains to restrain their collective wage choice. It can be shown that in the open-economy version of the model, the analogue to equation (15) is

$$
w^{c}=\left(1-\frac{\alpha \phi \Omega\{1-\alpha[1-(1-\phi) \Omega]\}\left(\eta-\beta^{2}\right)(1-\alpha)^{2} b_{w}}{\eta\{1-\alpha[1-(1-\phi) \Omega]\}[\lambda(1-\alpha)+1]+\beta^{2}(1-\Omega) \lambda}\right) p^{e}
$$

This expression indicates that an increase in the propensity to import, $\beta$, unambiguously boosts the contracted wage for coordinating wage setters, implying that their optimal wage choice is increasing in the degree of openness. This tends to boost equilibrium inflation in an economy containing wage-coordinating wage setters. ${ }^{4}$

In light of the contrasting effects of these two channels, solution of the openeconomy version of the model yields very unwieldy analytical expressions that imply an ambiguous overall effect of greater openness on the equilibrium inflation rate. Nevertheless, it is possible, from the perspective of Figure 1, to reason out the how the channels by which openness affects inflation vary in their effects depending on the degree of wage centralization in the economy. At low degrees of wage centralization, greater openness is more likely to rotate the inflation-wage centralization relationship downward along the leftward portion of the relationship. At higher degrees of wage centralization, along the rightward portion of the relationship, the tendency for coordinating wage setters to bargain for higher wages as the economy becomes more open yields an upward rotation. Increased openness, therefore, is more likely to reduce inflation in nations with a relatively low extent of wage-bargaining centralization but is 
more likely to raise inflation in countries with more centralized wage-setting arrangements.

Our analysis has emphasized two channels by which the degree of openness influences the inflation-wage centralization relationship. The first is the traditional channel arising from the structural macroeconomic effects of increased openness on the terms of the output-inflation trade-off (first proposed by Romer, 1993) and the priceresponsiveness of monetary policy actions (as discussed by Daniels and VanHoose, 2004). This channel tends to reduce equilibrium inflation in more open economies. The second channel arises from the rational response of coordinating wage setters to the reduced effect of their common wage choice on the equilibrium price level in a more open economy, namely to relax their restraint of nominal wage growth, which contributes to higher equilibrium inflation. The joint implication of these two channels by which greater openness affects inflation is that increased openness is more likely to be associated with lower inflation in nations with less centralized wage bargaining.

\section{Empirical Implications and Evidence}

Three empirical implications emerge from the forgoing discussion:

i) inflation initially rises when an increased share of firms have wage setters that coordinate their wage setting activities but then declines with ever-increasing centralization of wage bargaining;

ii) the inflation-restraining effect of increased central bank conservatism will be lessened under more centralized wage setting; and

iii) increased openness is more likely to reduce inflation in nations with less centralized wage bargaining.

Testing these hypotheses requires an indicator of the degree to which collective bargaining activities are coordinated within individual nations. A variety of authors, 
including Iversen (1999a), Golden, Lange and Wallerstein (2002), OECD (1997), Cukierman and Lippi (1999), Calmfors et al. (2001) (based on Visser, 2000), and Kenworthy (2001), have attempted to construct such indicators. Of these, Kenworthy's provides a frequency of observations and covers a period of time consistent with the other macroeconomic data we analyze to examine determinants of inflation.

Kenworthy's (2001, pp. 2-3) index of wage-setting coordination consists of the following five categories:

1 = Fragmented wage bargaining, confined largely to individual firms or plants.

$2=$ Mixed industry- and firm-level bargaining, with little or no pattern-setting and relatively weak elements of government coordination such as setting of basic pay rate or wage indexation.

$3=$ Industry-level bargaining with somewhat irregular and uncertain pattern-setting and only moderate union concentration; government wage arbitration.

4 = Centralized bargaining by peak confederation(s) or government imposition of a wage schedule/freeze, without a peace obligation; informal centralization of industry- and firm-level bargaining by peak associations; extensive, regularized pattern-setting coupled with a high degree of union concentration.

5 = Centralized bargaining by peak confederation(s) or government imposition of a wage schedule/freeze, with a peace obligation; informal centralization of industrylevel bargaining by a powerful, monopolistic union confederation; extensive, regularized pattern-setting and highly synchronized bargaining coupled with coordination of bargaining by influential large firms.

In light of the facts that the centralization index is completely discrete and that no theoretical prior exists as to exactly where the peak of the hump-shaped inflationcentralization relationship should be located, we follow the procedure suggested by Cukierman and Lippi (1999) by using five dummy variables (CORD1, CORD2, ..., CORD5) to represent these categories. ${ }^{5}$

The other variables used in our empirical model for testing our three hypotheses are as follows: ${ }^{6}$ 
(1) the inflation rate (INF), which is based on the GDP deflator using data from the IMF International Financial Statistics;

(2) the degree of central bank independence (CBI), taken from Franzese (2002), which is a weighted average of legal independence, a characterization of independence based on answers to a survey completed by individual at central banks (Cukierman, 1992), economic independence, political independence (Grilli, et al., 1991), and Bade and Parkin's (1982) index of central bank independence; and

(3) openness expressed as the ratio of imports to GDP using data from Ghosh et al. (2002).

Table 1 contains descriptive statistics on the sample data. Table 2 reports the estimation results based on an annual sample of 17 countries covering the period, 1970-1999. ${ }^{7}$ All regressions are estimated using OLS with the standard errors corrected for serial correlation using the Newey-West procedure.

The first column contains the results from a base specification that does not control for the degrees of openness and central bank independence. The estimated coefficients on the five dummy variables representing the degrees of wage centralization (CORD1, CORD2, CORD3, CORD4, and CORD5) are individually and jointly significant $(F=8.41, p$-value $=0.00)$. Moreover, these estimates form a humpedshaped pattern. The estimates rise from an initial value of $5.14($ CORD1 $=$ fragmented wage bargaining,) reaching a peak of 7.56 (CORD3 = industry-level bargaining with somewhat irregular and uncertain pattern-setting and only moderate union concentration; government wage arbitration. They end with an estimated value of 6.48 (CORD5 = centralized bargaining coupled with coordination of bargaining by influential large firms), which is larger than the estimate corresponding to CORD4 but lower than the peak value at CORD3. 
The empirical specification reported in the second column of Table 2 adds openness to the measures of wage bargaining coordination. The coefficient estimate for this additional new variable has the expected negative sign and is statistically significant at the $10 \%$ level. Furthermore, the estimated parameters associated with the five centralization dummy variables follow the same general humped-shaped pattern as in the regression without inclusion of openness (column 1).

The regression equation in the third column of Table 2 replaces openness with central bank independence $(\mathrm{CBI})$, which the basic theoretical framework indicates should also play a fundamental role in influencing inflation. This specification yields results that are generally consistent with those in the preceding columns, and the adjusted coefficient of determination is somewhat larger (69\% versus $66 \%){ }^{8}$

In the specification reported in the fourth column, therefore, we include both openness and $\mathrm{CBI}$, in addition to the five dummy variables representing the structure of wage bargaining. Once again, the results are in general conformity with those in earlier models. The adjusted $R^{2}$ from this regression is marginally greater than that of the model with CBI but without openness.

In order to test our second and third hypotheses regarding the effects of $\mathrm{CBI}$ and openness, the empirical specification reported in the fifth column of Table 2 includes an interaction of openness and $\mathrm{CBI}$ with wage-setting coordination. In contrast to the previous regressions that specified the five categories of wage bargaining centralization in terms of dummy variables, these additional explanatory variables in the final regression model interact the actual value of Kenworthy's discrete index with openness and $\mathrm{CBI}$ to test our second and third hypotheses. ${ }^{9}$

Note that the estimated coefficients on the five coordination dummy variables reported in the last column of Table 2 , which are individually and jointly significant, no longer form a pattern that is fully consist with Figure 1, thereby failing to support the first hypothesis that inflation initially rises with increased wags setting coordination and then 
declines as the centralization of wage bargaining continues to rise. ${ }^{10}$ Nevertheless, as in the earlier specifications, the estimated coefficients on openness and CBI have the expected negative sign and are statistically significant.

According to the second and third theoretical hypotheses, the two interaction terms should have positive coefficients. The estimated coefficients for the interaction terms added in the final regression are indeed positive and statistically significant, which provides support for these predictions. Thus, the data indicate that, consistent with our theoretical analysis, the inflation-restraining effect of increased central bank independence is diminished under more centralized wage setting, and increased openness reduces inflation under less centralized wage bargaining. ${ }^{11}$

Except for the fifth regression, the results in Table 2 are consistent with those reported by Iversen (1999b, P. 250, Table 2). It is reassuring that even though both Iversen's study and our analysis use different samples and different measures of $\mathrm{CBI}$ and wage-setting coordination, they still arrive at the same overall conclusion regarding the humped-shape of the inflation-coordination relationship and the effect of $\mathrm{CBI}$ on this relationship. Our study additionally considers the interaction between the degree of openness of the economy and the extent of collective bargaining coordination.

We examined the robustness of our results in a number of ways. First, we estimated the broadest model in Table 2 (regression 5) using actual values of Kenworthy's indicator of wage-setting coordination and its squared value instead of the five dummy variables representing the five categories of the indicator. The results did not fully support the hypothesized humped-shape of the effect of coordination on inflation. The squared estimated coefficient on the squared of the coordination index had the expected negative sign and was statistically significant, while the coefficient estimate for the index itself was neither positive nor statistically significant. The results using actual index values did, however, support our second and third hypotheses that 
increased centralization of wage bargaining reduces the inflation-lowering effects of increased openness and central bank independence.

In addition, we replaced Franzese's (2002) index of CBI with the legal index of central bank independence developed by Cukierman, et al. (1992) and Cukierman (1992), which ranges continuously between zero (least independent) to one (most independent) to re-estimate the fifth regression in Table 2. The fundamental empirical results did not seem to be sensitive to this change. Interestingly, when we replace Franzese's CBI index with the central bank turnover index (Ghosh et al. 2002), in all cases, including the broadest model in column 5 of Table 2, we found the hump-shaped pattern of wage-setting coordination, although there was a loss of statistical significance for some of the estimates. This means that the results may not be entirely robust to the selected measure of central bank independence.

We also incorporated some of the recent developments relating to the relationship between openness and inflation. As documented by Levin and Piger (2002) and Ihrig and Marquez (2003), time series inflation data exhibit a break around the late 1980s and early 1990s, and Bleaney (1999) notes that around the time of this same break the economic and statistical significance of the openness-inflation relationship began to diminish among developing nations. To control for this we included a dummy variable for the period after 1988 and obtained results that were not markedly different from those reported in reported in the final specification in Table 2. Furthermore, following Alfaro (2002) who noted that exchange-rate regimes influence the nature of the openness-inflation relationship, we incorporated indicators of pegged, intermediate, and floating rate regimes developed by Ghosh et al. (2002) both additively and multiplicatively as interactions with openness. Once again, the results were robust to the inclusion of exchange rate regimes. ${ }^{12}$

To better understand the interaction terms in the regression model 5 , we present the estimated marginal effect of central bank independence and the estimated marginal 
effect of openness for the range of values of centralized wage coordination along the lines suggested by Kam and Franzese (2005). We use CLARIFY (Tomz et al., 2001) to generate the simulated expected values of the marginal effect as described by King et al. (2001). Following the estimation of regression model 5, we draw 1,000 simulations of the estimated model parameters from their asymptotic sampling distribution. To generate the marginal effect of central bank independence for various values of wage coordination, all CORD dummies, openness, and the interactive term of openness and wage coordination are set at zero, and central bank independence is set equal to unity. This yields the marginal effect of $\mathrm{CBI}$, $d($ Inflation $) / d(C B I)=\beta_{C B I}+\beta_{C B I} \cdot$ Cord Cord. We then set Cord at a given value, say unity, and, using simulated parameters values, we generate the average expected value, standard error, and 95 percent confidence interval at each value of Cord.

Simulated expected values and the confidence interval are presented in Figure 2. The marginal effect of $\mathrm{CBI}$ is negative and always bounded away from zero, indicating a significant negative marginal effect of central bank independence for all degrees of wage coordination. (If extended to the vertical axis, in which case Cord would assume a value of zero, the intercept would equal the coefficient on CBI.) The positive slope of the marginal effect depicted in Figure 2 shows that, consistent with our theoretical predictions, increased CBI reduce inflations less in countries with a relatively larger degree of centralized wage coordination relative. The shape of the confidence interval illustrates a higher degree of certainty regarding the simulated expected values near the mean value of Cord and a lower degree of certainty moving away from the mean value.

\section{[Figure 2 Goes Here]}

Figure 3 displays the results when the same basic procedure is used to generate the marginal effect of openness on inflation for different degrees of centralized wage 
coordination. The marginal effect of openness on inflation also has a positive slope, indicating that increased openness tends to have a greater dampening effect on inflation in countries with lower levels of centralized wage coordination. Consistent with the theoretical prediction that greater openness could potentially boost inflation under centralized wage bargaining, in Figure 3 the simulated mean marginal effect is positive at the highest level of Cord-though the confidence interval spans the horizontal axis, indicating uncertainty regarding this conclusion.

\section{[Figure 3 Goes Here]}

Finally, we repeated the basic approach reported in Table 2 by replacing Kenworthy's index of wage-setting coordination with the net union density data reported by Ebbinghaus and Visser (2000). These data best proxy for the overall share of unionization $(\Omega)$ in our theoretical model and thus do not fully capture the extent to which wage setting is centralized, but they allow us to consider an annual frequency, albeit only for twelve countries covering the years 1970-1992. Using these data to test our first hypothesis concerning the pattern of the effect of unionization on inflation, we entered net union density both linearly and as a quadratic term in place of measures based on Kenworthy's centralization index. Our first hypothesis implies that the former should have a positive effect and the latter a negative effect. Estimation results, which are reported in Table 3, support our theoretical predictions concerning the effect of union density on inflation once effects of central bank independence and/or openness are taken into account. The results reported in Table 3 also support our theoretical hypotheses regarding the impacts of openness and $\mathrm{CBI}$; the coefficient estimates for these variables are negative and statistically significant in all cases (Columns 2-5). Although the estimated coefficients on the two interaction terms are positive, consistent with our theory, the coefficient estimates are statistically insignificant. Hence, to the 
extent that net union densities provide an indication of overall unionization rates that might engender wage-setting coordination, using this measure provides at least partial support for concluding that the results reported in Table 2 provide robust implications concerning the relevance of our theoretical model.

\section{Conclusion}

This paper has offered two contributions to understanding the relationship between macroeconomic performance and the degree of centralization of wage bargaining. First, it has developed a macroeconomic framework for analyzing this relationship that accounts for the types of labor-market heterogeneities encountered in real-world economies. The model developed in this paper has permitted the evaluation of discretionary monetary policy choices in an environment incorporating wage determination in spot markets for labor, wage setting at individual firms, and coordinated wage determination by a group of wage setters. In this setting, coordinating wage setters have an incentive to restrain nominal wage growth in light of their recognition that higher wages contribute to inflation. What naturally emerges is this setting is a hypothesized hump-shaped relationship between equilibrium inflation and the extent to which wage bargaining is centralized among coordinating wage setters, along with the prediction that the inflation-restraining effect of increased central bank conservatism will be lessened under more centralized wage setting. Furthermore, our framework implies that increased openness should tend to have a greater inflation-restraining impact in nations in which wage bargaining is less centralized.

Empirical evaluation of data encompassing inflation, centralization of wage setting, openness and centralization for seventeen nations between 1970 and 1999 provides considerable support for all three of these theoretical predictions. These results are robust to consideration of the potential change in the inflation-openness relationship after 1988 and alternative exchange-rate regimes, and the theory also 
receives qualified support from alternative empirical specifications in which net union densities are used as an imperfect proxy for the degree of wage centralization.

Our analysis, therefore, provides strong support for Cukierman and Lippi's (1999) work extending the Calmfors-Driffill (1988) hypothesis regarding the relationship between centralized wage setting and inflation to encompass additional effects of central bank independence. In contrast to Cukierman and Lippi, however, our theoretical framework does not hinge on the assumption that a nation's entire workforce is unionized, and it also allows us to assess additional impacts resulting from a change in the degree of openness, which Romer (1993) has shown also explains cross-country inflation performances. It thereby provides a broader indication of the range of interactions among fundamental structural characteristics-centralization of wage setting, central bank independence, and openness-in the determination of national inflation performances.

Undoubtedly, such institutional features of a nation's economy are explained by deeper characteristics that interact in a broad political-economy setting. Thus, our analysis suggests more broadly that scholars might benefit from pursuing politicaleconomy approaches such as those suggested by Iversen (1999a), Calmfors, et. al. (2002), and Franzese (2002), perhaps by building on recent work on political economics summarized in Drazen (2000) and Persson and Tabellini (2000).

More narrowly, we see three ways that our analysis might be generalized in potentially fruitful ways. Inclusion of firm-level and/or aggregate productivity, expenditure, and monetary disturbances that were explicitly ignored in the present paper would, for instance, permit consideration of implications of how openness influences both inflation volatility and the endogenous determination of both the extent to which wage contracts are utilized and the degree to which wage bargaining is centralized. In addition, allowing for competitive imperfections in product markets would be a useful, albeit significantly complicating, extension, because allowing for product- 
market imperfections would considerably generalize and thereby render more realistic the range of actions by centralized wage setters who recognize that their choices influence the incentives faced by monetary policymakers. Finally, relaxing the assumption of constant output and prices in the rest of the world and extending the model to a two- or multi-country setting would facilitate analysis of possible cross-border spillover effects of increased openness on interdependent monetary policies and inflation outcomes. We leave consideration of these and other potentially interesting extensions to future research. 


\section{Table 1}

\section{Descriptive Statistics}

$\begin{array}{ccccc} & \text { Inflation } & \text { Coordination } & \text { CBI } & \text { Openness } \\ \text { Mean } & 5.83 & 3 & 50.70 & 29.25 \\ \text { Median } & 4.80 & 3 & 47.38 & 27.91 \\ \text { St. Dev. } & 4.34 & 0.73 & 19.84 & 13.53\end{array}$




\section{Table 2 \\ Alternative Estimates of Inflation}

Annual Panel of 17 Countries, 1970-1999

(Absolute Values of t-Ratios based on Newey-West Robust Standard Errors in Parentheses)

\begin{tabular}{|l|c|c|c|c|c|}
\hline & $(1)$ & $(2)$ & $(3)$ & $(4)$ & $(5)$ \\
\hline Cord1 & 5.14 & 5.75 & 9.04 & 10.24 & 19.10 \\
& $(10.76)$ & $(9.66)$ & $(10.60)$ & $(9.87)$ & $(7.33)$ \\
\hline Cord2 & 6.94 & 7.51 & 9.68 & 10.75 & 15.73 \\
& $(7.73)$ & $(7.86)$ & $(9.44)$ & $(9.41)$ & $(9.79)$ \\
\hline Cord3 & 7.56 & 8.42 & 9.98 & 11.48 & 14.86 \\
& $(9.52)$ & $(8.81)$ & $(11.33)$ & $(10.08)$ & $(11.43)$ \\
\hline Cord4 & 4.66 & 5.61 & 8.66 & 10.40 & 11.10 \\
& $(11.72)$ & $(7.61)$ & $(9.27)$ & $(8.11)$ & $(8.92)$ \\
\hline Cord5 & 6.48 & 7.34 & 9.43 & 10.97 & 8.56 \\
& $(14.45)$ & $(9.12)$ & $(13.43)$ & $(9.77)$ & $(6.36)$ \\
\hline Openness & & -0.03 & & -0.04 & -0.3 \\
& & $(1.63)^{*}$ & & $(2.35)^{* *}$ & $(5.23)$ \\
\hline CBI & & & -0.07 & -0.07 & -0.17 \\
& & & $(5.66)$ & $(5.91)$ & $(4.04)$ \\
\hline Cord*Openness & & & & & 0.06 \\
& & & & & $(4.23)$ \\
\hline Cord*CBI & & & & & 0.02 \\
& & & & & $(2.37)^{\star *}$ \\
\hline Adjusted R & & & & & \\
\hline F Statistic & 8.41 & 7.44 & 15.64 & 14.68 & 13.89 \\
\hline Number of & 510 & 510 & 510 & 510 & 510 \\
\hline Observations & & & & & \\
\hline
\end{tabular}

*Significant at the $10 \%$ level

**Significant at the $5 \%$ level

All other estimates are significant at the $1 \%$ level

Glossary

Cord $=$ index of wage-setting coordination (Kenworthy, 2001)

Cord 1 = dummy variable equals 1 for fragmented (decentralized) bargaining

Cord2 = dummy variable equals 1 for mixed industry- and firm-level bargaining

Cord3 = dummy variable equals 1 for industry-level bargaining and moderate union concentration

Cord 4 = dummy variable equals 1 for centralized wage bargaining

Cord5 = dummy variable equals 1 for centralized wage bargaining along with centralization of bargaining by influential firms

Openness $=$ ratio of imports to GDP

$\mathrm{CBI}=$ index of central bank independence (Franzese, 2002) 
Table 3

Alternative Estimates of Inflation

Annual Panel of 12 countries, 1970-1992

(Absolute Values of t-Ratios based on Newey-West Robust

Standard Errors in Parentheses)

\begin{tabular}{|l|c|c|c|c|c|}
\hline & $(1)$ & $(2)$ & $(3)$ & $(4)$ & $(5)$ \\
\hline Constant & 2.71 & 4.29 & 8.59 & 9.61 & 11.37 \\
& $(1.63)^{*}$ & $(2.70)$ & $(4.63)$ & $(5.25)$ & $(3.62)$ \\
\hline Union & 0.15 & 0.25 & 0.13 & 0.22 & 0.18 \\
& $(2.05)^{* *}$ & $(3.14)$ & $(1.84)^{*}$ & $(2.80)$ & $(1.69)^{*}$ \\
\hline Union ${ }^{2}$ & -0.001 & -0.002 & -0.001 & -0.002 & -0.002 \\
& $(1.54)$ & $(2.59)$ & $(1.84)^{*}$ & $(2.69)$ & $(2.67)$ \\
\hline Openness & & -0.11 & & -0.10 & -0.16 \\
& & $(4.10)$ & & $(3.71)$ & $(2.54)^{* *}$ \\
\hline CBI & & & -0.09 & -0.08 & -0.09 \\
& & & $(6.38)$ & $(6.69)$ & $(2.46)^{* *}$ \\
\hline Union*Openness & & & & 0.13 \\
& & & & & 0.01 \\
\hline Union*CBI & & & & & $(0.16$ \\
\hline Adjusted R ${ }^{2}$ & 0.04 & 0.12 & 0.18 & 0.24 & 0.24 \\
\hline F Statistic & 6.71 & 13.07 & 21.01 & 22.51 & 15.10 \\
\hline Sample Size & 276 & 276 & 276 & 276 & 276 \\
\hline
\end{tabular}

*Significant at the $10 \%$ level

** Significant at the $5 \%$ level

All other estimates are significant at the $1 \%$ level

Glossary

Union = net union density (Ebbinghaus and Visser, 2000)

Openness $=$ ratio of imports to GDP

$\mathrm{CBI}=$ index of central bank independence (Franzese, 2002) 
Figure 1

Inflation Simulations

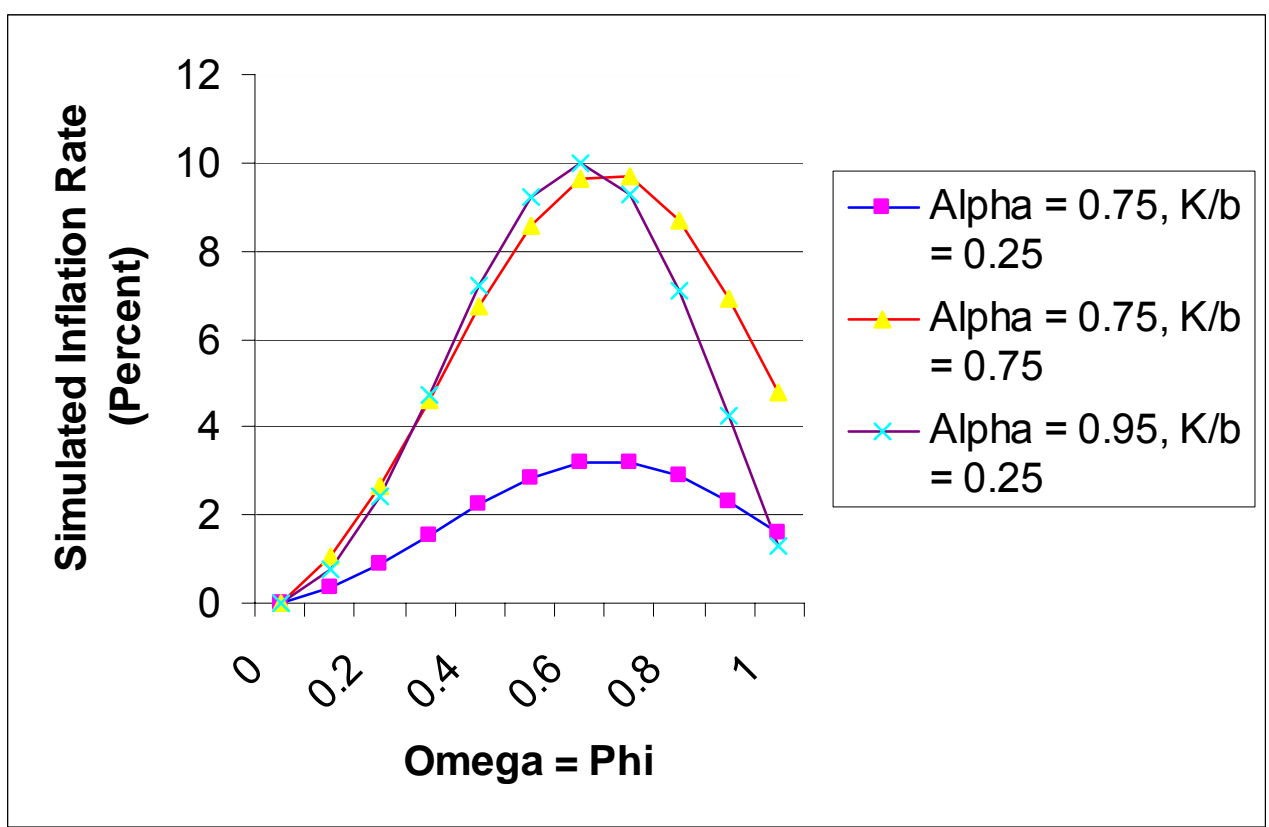




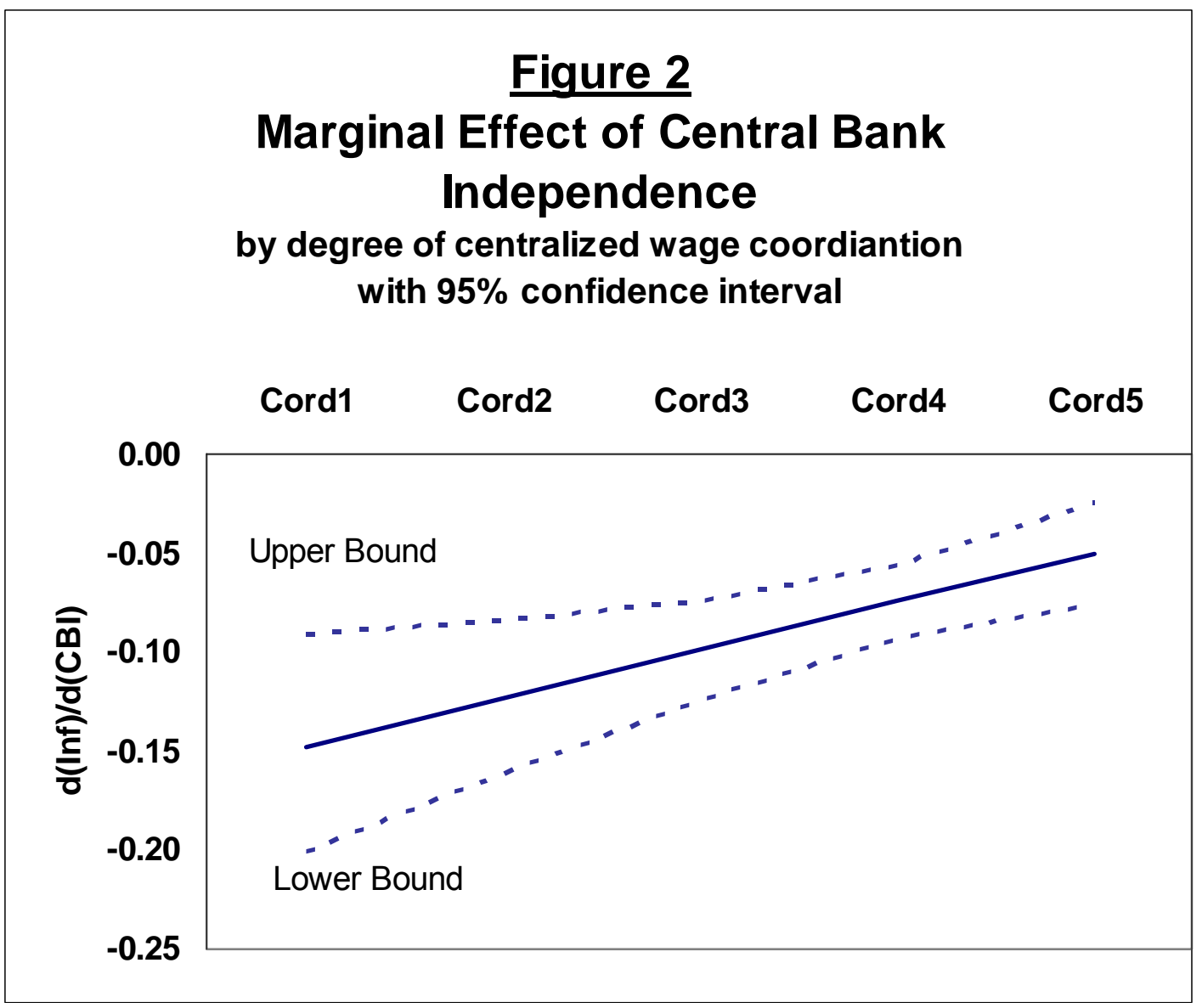




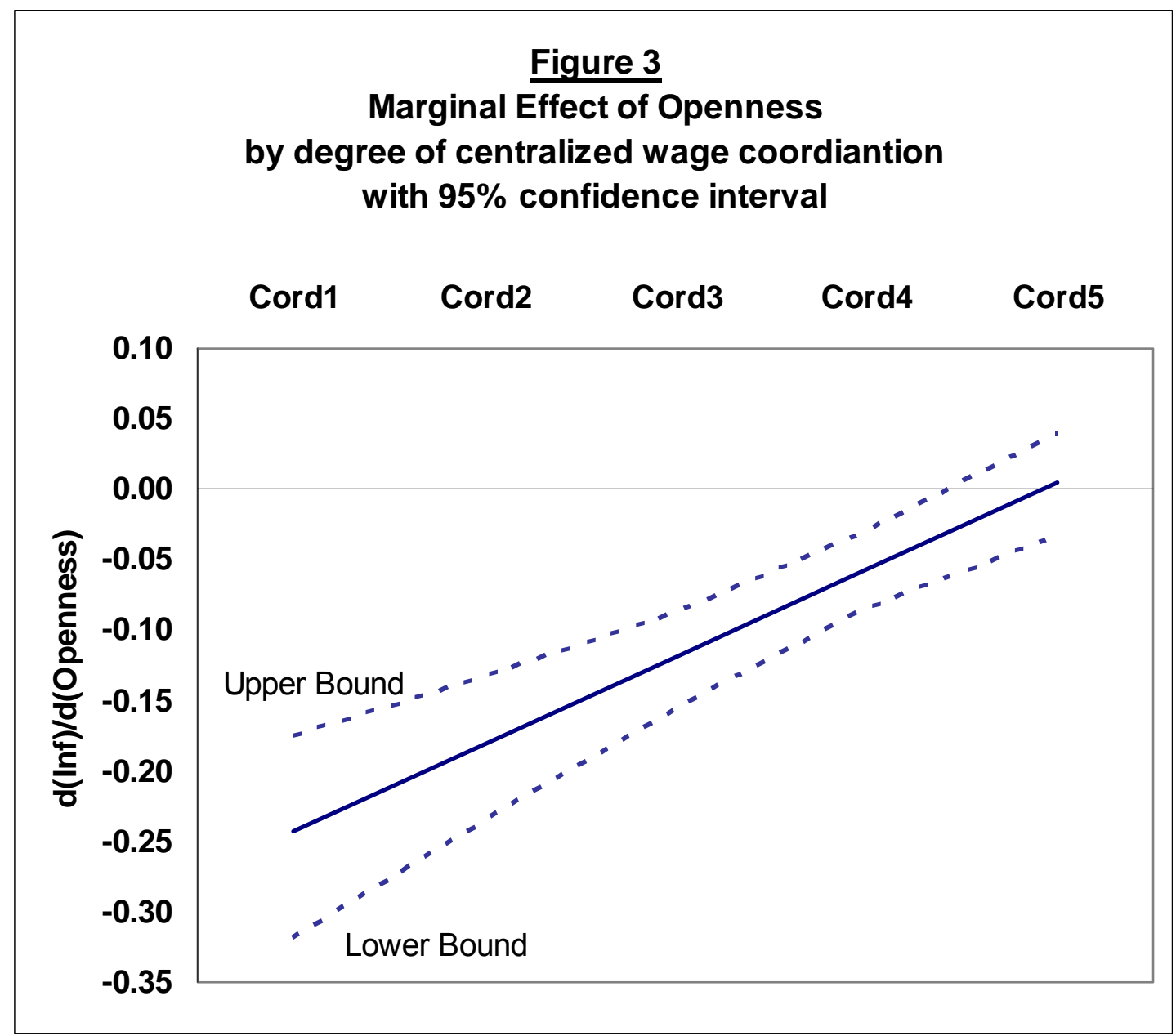




\section{REFERENCES}

Al-Marhubi, Fahim, and Thomas Willett, 1995, The anti-inflationary influence of corporatist structures and central bank independence: The importance of the hump shaped hypothesis, Public Choice, 84, 153-162.

Alfaro, Laura, 2002, Inflation, openness, and exchange-rate regimes, Unpublished Manuscript, Harvard Business School, July.

Bade, Robin, and Michael Parkin, 1982, Central bank laws and monetary policy, Unpublished Manuscript, University of Western Ontario.

Ball, L., 1988, Is equilibrium indexation efficient? Quarterly Journal of Economics 103 (2), 299-311.

Barro, R.J., D.B. Gordon, 1983. A positive theory of monetary policy in a natural rate model, Journal of Political Economy 91 (2), 589-610.

Bleaney, Michael, 1999, The disappearing openness-inflation relationship: A crosscountry analysis of inflation rates, IMF Working Paper WP/99/161, December.

Bryson, Jay, Henrik Jensen, and David VanHoose, 1993, Rules, discretion, and international monetary and fiscal policy coordination, Open Economies Review 4 (2), 117-132.

Calmfors, Lars, 2001, Wages and wage-bargaining institutions in the EMU—a survey of the issues, Institute for International Economic Studies, Seminar Paper No. 690, May.

Calmfors, Lars, Alison Booth, Michael Burda, Daniele Checchi, Robin Naylor, and Jelle Visser, 2001, The future of collective bargaining in Europe, in Boeri, Tito, Agar Brugiavini, and Lars Calmfors, eds., The Role of Unions in the Twenty-First Century, Oxford: Oxford University Press, pp. 1-156.

Calmfors, Lars, and John Driffill, 1988, Bargaining structure, corporatism, and macroeconomic performance, Economic Policy, 3 (1), 14-61. 
Canzoneri, Matthew, and Dale Henderson, 1991, Monetary Policy in Interdependent Economies: A Game Theoretic Approach. MIT Press, Cambridge, MA.

Cubitt, Robin, 1995, Corporatism, monetary policy, and economic performance: a simple game-theoretic analysis, Scandinavian Journal of Economics, 92 (1), 245249.

Cubitt, Robin, 1992, Monetary policy games and private sector precommitment, Oxford Economic Papers, 44 (3), 513-530.

Cukierman, Alex, 1992, Central Bank Strategy, Credibility and Independence: Theory and Evidence, Cambridge MA: MIT Press.

Cukierman, Alex, and Francesco Lippi, 1999, Central bank independence, centralization of wage bargaining, inflation and unemployment: theory and evidence, European Economic Review, 43 (7), 1395-1434.

Daniels, Joseph, and David VanHoose, Forthcoming, "Openness, the Sacrifice Ratio, and Inflation: Is There a Puzzle?" Journal of International Money and Finance.

Drazen, Allan, 2000, Political Economy in Macroeconomics, Princeton: Princeton University Press.

Duca, John, and David VanHoose, 2000. Has greater competition restrained inflation? Southern Economic Journal 66 (3), 729-741.

Duca, John, and David VanHoose, 2001. The rise of goods-market competition and the fall of wage contracting: endogenous wage contracting in a multisector economy. Journal of Macroeconomics 23 (1), 1-29.

Ebbinghaus, Bernhard, and Jelle Visser, 2000, The Societies of Europe: Trade Unions in Western Europe since 1945, London: Macmillan Reference Ltd.

Eijffinger, Sylvester, Marco Hoeberichts, and Eric Schaling, 2000, Optimal central bank conservatism in an open economy, Public Choice, 105, 339-335. 
Fischer, Stanley, 1986, "Toward and Understanding of the Costs of Inflation II," in Stanley Fischer, ed., Indexing, Inflation, and Economic Policy, Cambridge, MA: MIT Press, pp. 35-69.

Franzese, Robert, Jr., 2004, "'Strategic Interactions of the ECB, Wage Bargainers, and Governments," in P. Mooslechner, M. Schuerz, R., Franzese, eds., Institutional Conflicts and Complementarities: Monetary Policy and Wage Bargaining Institutions in EMU, Amsterdam: Kluwer, pp. 5-24.

Franzese, Robert, Jr., 2002, Macroeconomic Policies of Developed Democracies, Cambridge, UK: Cambridge University Press.

Franzese, Robert, Jr., 2001, Institutional and structural interactions in monetary policy and wage/price bargaining, in Varieties of Capitalism: The Institutional Foundations of Comparative Advantage, ed. Peter Hall and David Soskice, Cambridge, UK: Cambridge University Press.

Franzese, Robert, Jr., and Peter Hall, 1998, Central bank independence, coordinated wage bargaining, and European Monetary Union, International Organization, 52 (3), 505-536.

Ghosh, Atish, Anne-Marie Gulde, and Holger Wolfe, 2002, Exchange Rate Regimes: Choices and Consequences, Cambridge, MA: MIT Press.

Golden, Miriam, Peter Lange, and Michael Wallerstein, 1997, Union coordination among advanced industrial societies: An Empirical Study, University of California at Los Angeles.

Grilli, Vittorio, Donato Masciandaro, and Guido Tabellini, 1991, Political and monetary institutions and public financial policies in the industrial countries, Economic Policy, 13, 341-392.

Guzzo, Vincenzo, and Andres Velasco, 1999, The case for a populist central banker, European Economic Review, 43 (7), 1317-1344. 
Ihrig, Jane, and Jaime Marquez, 2003, An empirical analysis of of inflation in OECD countries, International Finance Discussion Paper No. 765, Board of Governors of the Federal Reserve System, May 2003.

Iversen, Torben, 1998, Wage bargaining, central bank independence, and the real effects of money, International Organization, 52 (3): 469-504.

Iversen, Torben, 1999a, Contested Economic Institutions, Cambridge, UK: Cambridge University Press.

Iversen, Torben, 1999b, The political economy of inflation: Bargaining structure or central bank independence? Public Choice, 99, 237-258.

Iversen, Torben, Jonas Pontusson, and David Soskice, 2000, Unions, Employers, and Central Banks, Cambridge, UK: Cambridge University Press.

Kam, Cindy D., and Robert J. Franzese, Jr., 2005. Modeling and Interpreting Interactive Hypothseses in Regression Analysis: A Refresher and Some Practical Advice, http://www-personal.umich.edu/ franzese/.

Kenworthy, Lane, 2001, Wage-setting measures: A survey and assessment, World Politics, 54 (1): 57-98.

King, Gary, Michael Tomz, and Jason Wittenberg, 2000, Making the most of statistical analysis: Improving interpretation and presentation, American Journal of Political Science 44 (2), 347-61.

Levin, Andrew, and Jeremy Piger, 2002, Is inflation persistence intrinsic in industrial economies? Federal Reserve Bank of St. Louis Working Paper 2002-023C.

McHugh, James, 2002, Wage centralization, union bargaining, and macroeconomic performance, IMF Working Paper WP/02/143, August.

Modigliani, Franco, and Stanley Fischer, 1986, "Toward and Understanding of the Real Effects and Costs of Inflation," in Stanley Fischer, ed., Indexing, Inflation, and Economic Policy, Cambridge, MA: MIT Press, pp. 7-33. 
OECD, 1997, Economic performance and the structure of collective bargaining, Employment Outlook, 63-92.

Persson, Torsten, and Guido Tabellini, 2000, Political Economics: Explaining Economic Policy, Cambridge, MA: MIT Press.

Romer, David, 1993, Openness and inflation: theory and evidence, Quarterly Journal of Economics, 108: 869-904.

Skott, Peter, 1997, Stagflationary consequences of prudent monetary policy in a unionized economy, Oxford Economic Papers, 49 (4), 609-622.

Soskice, David, and Torben Iversen, 2000, The nonneutrality of monetary policy with large price or wage setters, Quarterly Journal of Economics, 115, 265-287.

Temple, Jonathan, 2002. Openness, inflation, and the Phillips curve: a puzzle. Journal of Money, Credit, and Banking 34 (2), 450-468.

Tomz, Michael, Jason Wittenberg, and Gary King, 2000, CLARIFY: Software for Interpreting and Presenting Statistical Results. Version 2.0 Cambridge, MA: Harvard University, June 1, http://gking.harvard.edu.

Visser, Jelle, 2000, A combined indicator of union centralization and coordination, Amsterdam Institute for Advanced Labor Studies, Working Paper No. 00/3. 


\section{FOOTNOTES}

${ }^{1}$ The assumption of perfect competition in product markets simplifies exposition and analysis of the model, which already becomes quite complex when openness is considered below. As noted in the conclusion, generalizing to the case of imperfect competition in this framework would be a useful direction for future work, because in such a setting labor demand would become less sensitive to the product price, and wage setters are more likely to seek higher wages in the face of monopolistic exploitation in the labor market.

2 Note that this implies that a potential exists for a conflict of interest among workers regarding real exchange rate movements, which might be contemplated in a politicaleconomy application of this framework that we do not pursue here.

${ }^{3}$ We could also include a real wage objective in the analysis, in which case a real-wage target would appear throughout all subsequent expressions, but none of the substantive implications would be affected.

${ }^{4}$ Thus, more open economies with centralized wage setting would benefit from greater central bank independence, which is consistent with the results derived by Eijffinger et al. (2000) using a more standard Barro-Gordon-style framework.

${ }^{5}$ For most of the countries in the sample, Kenworthy's index of wage-setting coordination is not time-invariant. This measure is constant for four countries in the sample (France, Germany, Japan, and Switzerland), but for the remaining thirteen countries the series has a standard deviation ranging from 0.43 (Finland) to 1.44 (UK).

${ }^{6}$ The data in all three of these non-binary series are percentages expressed as whole numbers. 
7 The nations we consider are Australia, Austria, Belgium, Canada, Denmark, Finland, France, Germany, Italy, Japan, the Netherlands, New Zealand, Norway, Sweden, Switzerland, the United Kingdom, and the United States.

8 The regression equations in Table 1 do not contain an intercept term, because our goal is to test the hypothesized humped-shape of the effect of coordination on inflation. Doing so necessitates including all five categories of the wage-setting coordination index in the regression equation. As a result, the usual coefficient of determination, $R^{2}$ defined as the ratio of the explained sums of squares to the total sums of squares, is no longer valid. Instead, one use the sum of squared predicted values divided by the sum of squared observed values of the dependent variable as a measure of goodness of fit of the estimated equation. This ratio, adjusted for the number of degrees of freedom, is what is reported in Table 1.

${ }_{9}^{9}$ As an alternative approach, we crossed all possible permutations of the five dummy coordination variables with openness and $\mathrm{CBI}$, which resulted in generally mixed results with no particularly discernable pattern.

${ }^{10}$ We replaced Franzese's CBI index with the central bank turnover index (Ghosh et al. 2002) and re-estimated all five models. In all cases, including the broadest model in column 5 of Table 2, we found the hump-shaped pattern of wage-setting coordination though there was a loss of statistical significance for some of the estimates. This means that the results may not be robust to the measure of central bank independence.

${ }^{11}$ It is important to note that interaction terms are inherently symmetrical in the sense that if the marginal effect of $\mathrm{CBI}$ on inflation depends on wage-setting coordination, then it must be that the marginal effect of coordination would in turn be a function of $\mathrm{CBI}$. Moreover, if the former effect is a diminishing function of coordination, then the latter effect would also be a declining function of $\mathrm{CBI}$. 
${ }^{12}$ We arrived at the same conclusion when we interacted the exchange rate regime variables with the other regressors in the model. 